\title{
Oligonucleotide Probes Complementary to Variable Regions of Ribosomal RNA Discriminate between Mycoplasma Species
}

\author{
By ULF B. GÖBEL, ${ }^{*}$ ANDREW GEISER ${ }^{2}$ AND ERIC J. STANBRIDGE ${ }^{2}$ \\ ${ }^{1}$ Institut für Medizinische Mikrobiologie und Hygiene, Klinikum der Universität Freiburg, \\ Hermann-Herder-Str. 11, D-7800 Freiburg, FRG, \\ ${ }^{2}$ Department of Microbiology and Molecular Genetics, University of California, Irvine, CA 92717 , \\ USA
}

(Received 27 November 1986; revised 3 February 1987)

On the basis of information from computer-assisted sequence comparison of the Mycoplasma pneumoniae 16S ribosomal RNA (rRNA) sequences with sequences from various other mycoplasmal and bacterial species, we constructed $M$. pneumoniae-specific oligonucleotide probes complementary to variable regions in the $16 \mathrm{~S}$ rRNA molecule. Using a DNA/RNA dot blot hybridization procedure, it was possible to detect less than $1 \times 10^{3}$ mycoplasmas. This test is a most sensitive assay for species-specific detection of bacteria. It can easily be adapted for detection and identification of other bacterial species and may have wide medical and industrial application.

\section{INTRODUCTION}

Ribosomal RNAs (rRNAs) are essential constituents of bacterial and eukaryotic ribosomes (Morgan, 1982; Nomura et al., 1977). Their presence in high numbers, sometimes in excess of ten thousand molecules per cell, makes them an attractive target for diagnostic hybridization probes. That they have been little used for this purpose probably results from the substantial homology that exists among rRNAs from widely divergent prokaryotic organisms. At least for bacterial 16S rRNAs, however, computer-assisted sequence comparisons have revealed that highly conserved regions are interspersed by regions of moderate and low homology even with respect to closely related species (Woese et al., 1983; Gray et al., 1984). These observations indicated that it might be possible to construct species-specific probes based on synthetic oligonucleotides complementary to highly variable sequences in the 16S rRNA. To demonstrate the feasibility of such an approach, we have chosen as a model the fastidious and slow growing mollicute, Mycoplasma pneumoniae, a major cause of human pneumonia (Cassell \& Cole, 1981).

\section{METHODS}

DNA and RNA isolation. Mycoplasma pneumoniae strains FH and PI 1428 were grown and harvested in the lateexponential phase as described previously (Göbel et al., 1981). Other mycoplasmas were from the strain collection of E. J. Stanbridge, and cultivated as described elsewhere (Tully \& Razin, 1983). DNA was extracted as reported earlier (Göbel \& Stanbridge, 1984). For RNA extraction the bacterial suspension was mixed with an equal volume of $3 \mathrm{M}-\mathrm{LiCl}$ (Merck) and $6 \mathrm{M}$-urea (BRL) buffer (Auffray \& Rougeon, 1980) and allowed to solubilize at $0^{\circ} \mathrm{C}$ overnight.

Selection of sequences suitable for the construction of oligonucleotide probes and oligonucleotide synthesis. Fragments of $M$. pneumoniae strain FH genomic DNA, carrying parts of the 16S rRNA gene, were identified in a Southern blot experiment using a nick-translated probe (pKK3535) containing Escherichia coli 16S rRNA sequences (Brosius et al., 1978). The appropriate fragments were directly cloned into pUC8 or phage M13 mp8/9 (Messing, 1983) and sequenced by the dideoxy chain termination method (Sanger et al., 1977). Alignment of the $M$. pneumoniae 16S rRNA primary sequences with 16S rRNAs from two other mycoplasmas, five eubacteria, and one eukaryote is shown in Fig. 1. Computer-assisted sequence comparison allowed identification of regions suitable 
for the construction of two species-specific oligonucleotide probes, MP20 and MP30. The following species were compared: Mycoplasma capricolum (Iwami et al., 1984), Mycoplasma strain PG 50 (Frydenberg \& Christiansen, 1985), E. coli (Brosius et al., 1978), Proteus vulgaris (Carbon et al., 1981), Bacillus brevis, Bacillus stearothermophilus and Bacillus subtilis (Woese et al., 1983; Huysmans \& De Wachter, 1986), and Xenopus laevis (Salim \& Maden, 1981). The sequences correspond to the variable regions V3 (base 998-1043, Fig. 1 a) and V6 (base 447-487, Fig. $1 b$ ) of the E. coli 16S rRNA molecule (Gray et al., 1984).

The 20-base and 30-base probes were synthesized on a solid support by an Applied Biosystems 380A DNA synthesizer using diisopropylphosphoramidites (Atkinson \& Smith, 1984) and purified by preparative electrophoresis on a native $20 \%(\mathrm{w} / \mathrm{v})$ polyacrylamide gel. The correct sequence was confirmed by a modified Maxam-Gilbert sequencing procedure (Wu et al., 1984).

Hybridization. For Southern hybridization, genomic DNAs from the appropriate bacteria were digested with various restriction enzymes (see Fig. 2), following the suppliers' recommendations (Böhringer Mannheim; BRL; Pharmacia). The resulting fragments were separated on a $1 \%(w / v)$ agarose gel, blotted onto nylon filters (Pall) and hybridized to the [ $\gamma^{32}$ P]ATP-end-labelled oligonucleotide probes (Wallace et al., 1979, 1981; Conner et al., 1983). [ $\gamma^{32}$ P]ATP, $5000 \mathrm{Ci} \mathrm{mmol}^{-1}\left(185 \mathrm{TBq} \mathrm{mmol}^{-1}\right)$, was supplied by Amersham. Approximately $2-4 \times 10^{6}$ c.p.m. were applied to each filter. Both DNA/DNA and DNA/RNA hybridizations were performed for 1-2 h (MP20 was incubated at $53{ }^{\circ} \mathrm{C}$ and $\mathrm{MP} 30$ at $\left.70^{\circ} \mathrm{C}\right)$ in $5 \times$ SSC $(1 \times$ SSC is $0.15 \mathrm{M}-\mathrm{NaCl}, 0.015 \mathrm{M}$-sodium citrate $)$ containing $5 \times$ Denhardt's solution [ $1 \times$ Denhardt's solution is $0.02 \%(\mathrm{v} / \mathrm{v})$ bovine serum albumin, $0.02 \%(\mathrm{w} / \mathrm{v})$ polyvinylpyrrolidone and $0.02 \%(\mathrm{w} / \mathrm{v})$ Ficoll $], 0.2 \%(\mathrm{w} / \mathrm{v}) \mathrm{SDS}$ and $250 \mu \mathrm{g}$ yeast tRNA $\mathrm{ml}^{-1}$. The prehybridization was done for $\mathbf{3 0} \mathrm{min}$ at the appropriate temperature using the hybridization buffer.

After hybridization each filter was washed with two changes ( 1 min each) of $5 \times$ SSC containing $0 \cdot 2 \%(w / v)$ SDS at the appropriate hybridization temperature, dried and autoradiographed with Kodak XAR- 5 film between two intensifier screens (Du Pont) at $-70^{\circ} \mathrm{C}$ for $4-72 \mathrm{~h}$.

For 'slotblot' hybridization, samples of the DNA or RNA were spotted directly onto nylon membranes (Pall) using a slot-shaped filtration manifold (Minifold II, Schleicher \& Schüll). An M. pneumoniae suspension was vortexed and ultrasonicated to yield single cells. Samples from tenfold serial dilutions were tested for colony forming units (c.f.u.). Further samples of $50 \mu \mathrm{l}, 25 \mu \mathrm{l}$ and $10 \mu \mathrm{l}$ were spotted directly onto nylon filters.

For RNA extraction, the filter was placed for $30 \mathrm{~min}$ at room temperature onto a Whatman $3 \mathrm{MM}$ paper soaked with RNA-extraction buffer (Chirgwin et al., 1979). After drying it was hybridized as described above. The numbers of mycoplasmas in the undiluted suspensions were: $3 \times 10^{5}$ c.f.u., $1.5 \times 10^{5}$ c.f.u. and $7.0 \times 10^{4}$ c.f.u. for $50 \mu \mathrm{l}, 25 \mu \mathrm{l}$ and $10 \mu \mathrm{l}$ samples respectively. DNA was extracted as previously reported (Göbel \& Stanbridge, 1984).

To test the influence of the sample preparation procedure on the sensitivity of the RNA/DNA hybridization $50 \mu \mathrm{l} \mathrm{samples}$ of an $M$. pneumoniae suspension containing $2 \times 10^{9} \mathrm{c}$.f.u. $\mathrm{ml}^{-1}$ were either spotted immediately or after several cycles of freezing and thawing, baked for $2 \mathrm{~h}$ at $80^{\circ} \mathrm{C}$ and processed as described above. In an additional experiment two sputum samples, tested to be $M$. pneumoniae-free, were mixed with broth-grown $M$. pneumoniae cells in various concentrations. The sputum specimens were solubilized by adding equal volumes of either $20 \%(\mathrm{w} / \mathrm{v}) \mathrm{N}$-acetylcysteine (Sigma) in PBS (0.145 M-sodium chloride, $0.15 \mathrm{M}$-sodium phosphate, $\mathrm{pH} 7 \cdot 2)$ or $20 \%(w / v)$ DTT (Sigma) in PBS. After $30 \mathrm{~min}$ at $37^{\circ} \mathrm{C}$, samples of the mixture $(50 \mu \mathrm{l}, 20 \mu \mathrm{l}$ and $5 \mu \mathrm{l})$ were spotted onto the nylon membranes. After baking $\left(2 \mathrm{~h}, 80^{\circ} \mathrm{C}\right)$, filters were hybridized using ${ }^{32} \mathrm{P}$-labelled MP20 and processed as described above. Samples of tenfold serial dilutions of an $M$. pneumoniae suspension $\left(2 \times 10^{5}\right.$ c.f.u. $\mathrm{ml}^{-1}$ ) were used as controls.

\section{RESULTS AND DISCUSSION}

The $M$. pneumoniae $16 \mathrm{~S}$ rRNA sequence has approximately $70 \%$ homology to that $E$. coli (Brosius et al., 1978), a value which corresponds to those found for M. capricolum (Iwami et al., 1984) and Mycoplasma strain PG 50 (Frydenberg \& Christiansen, 1985). Alignment of the 16S rRNA sequences of $M$. pneumoniae, $M$. capricolum and Mycoplasma PG 50 allowed the identification of variable domains interspersed among highly conserved regions. (Fig. 1). Two oligo-deoxynucleotides, MP20 (20 bases long) and MP30 (30 bases long), complementary to the corresponding $M$. pneumoniae $16 \mathrm{~S}$ rRNA sequences, were synthesized and used as probes.

\section{Probe specificity}

Southern blot analysis of restriction enzyme digested mycoplasma and bacterial genomic DNA (Fig. 2) showed that both probes recognized the two $M$. pneumoniae strains used in this study. Comparison of the bands revealed by autoradiography with the published restriction map of the $M$. pneumoniae 16S rRNA (Göbel et al., 1984) showed that only the DNA fragments containing the relevant rRNA sequence hybridized to the probe. No bands were detected in the 


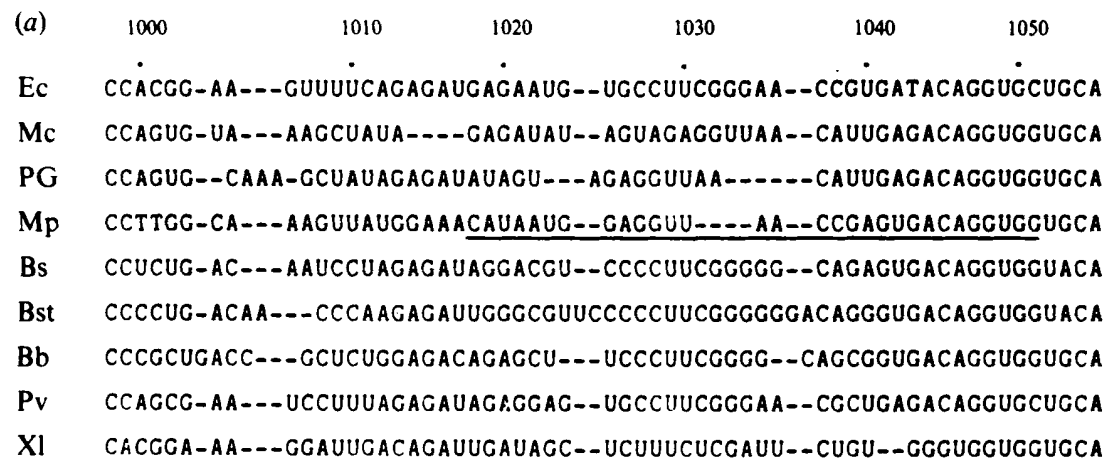

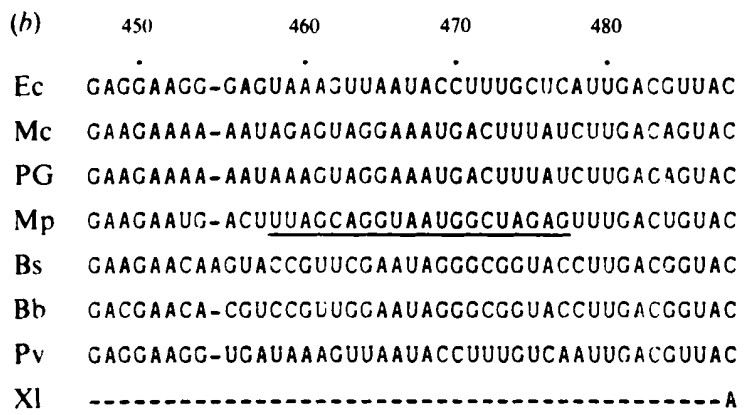

Fig. 1. Alignment of the M.pneumoniae (Mp) 16S rRNA primary sequences with 16S rRNAs from two other mycoplasmas, five eubacteria and one eukaryote. The sequences correspond to the variable regions V3 (base 998-1043, a) and V6 (base 447-487, b) of the E. coli 16S rRNA molecule. Hyphens have been inserted to facilitate alignment. The numbers indicate the appropriate base positions in the $E$. coli $16 \mathrm{~S}$ rRNA molecule. The sequences complementary to MP20 $(b)$ and MP30 $(a)$ are underlined. Bb, B. brevis; Bs, B. subtilis; Bst, B. stearothermophilus; Ec, E. coli; Mc, M. capricolum; PG, Mycoplasma PG 50; Pv, P. vulgaris; Xl, X. laevis.

lanes containing $M$. gallisepticum, $M$. hyorhinis or $E$. coli DNA (Fig. 2). The same probes failed to hybridize to the same amounts of DNA from other Mycoplasma species, including $M$. arginini G230, $M$. arthritidis PG6, $M$. bovirhinis PG43, . buccale CH20247, $M$. canis PG14, $M$. faucium DC-333, $M$. fermentans PG18, $M$. gallinarum PG16, $M$. gallisepticum PG31, $M$. hominis PG21, $M$. hyorhinis BTS-7, M. lipophilum Maby, M. maculosum PG15, M. neurolyticum Type A, M. orale $\mathrm{CH} 19299$, M. pulmonis ASh, M. salivarium PG20, Ureaplasma urealyticum 960, Acholeplasma granularum BTS-39, Acholeplasma laidlawii PG8, Acholeplasma oculi 19L and Spiroplasma citri strain Morocco (R8-A2) (data not shown).

The probe MP30, unexpectedly, cross-hybridized with DNA from $M$. genitalium, a mycoplasma which is closely related to $M$. pneumoniae (Razin, 1985), indicating considerable sequence homology even in variable domains of the rRNA molecule. MP20, however, was able to discriminate between both species (unpublished data).

\section{Sensitivity of the assay}

In order to measure the advantage gained by using rRNA as a hybridization target instead of genomic DNA, the following experiment was performed. Identical filters carrying dilutions of an $M$. pneumoniae suspension were hybridized to ${ }^{32} \mathrm{P}$-labelled MP30, using procedures appropriate for either a DNA/DNA or a DNA/RNA hybridization. The result (Fig. 3) showed that the DNA/RNA protocol was capable of detecting less than 1000 mycoplasmas, a sensitivity more than 100 times greater than that obtained when the RNA was degraded prior to hybridization. Sample preparation, however, played a crucial role for maximum sensitivity of the DNA/RNA hybridization procedure. When rRNA was prepared from an M. pneumoniae 


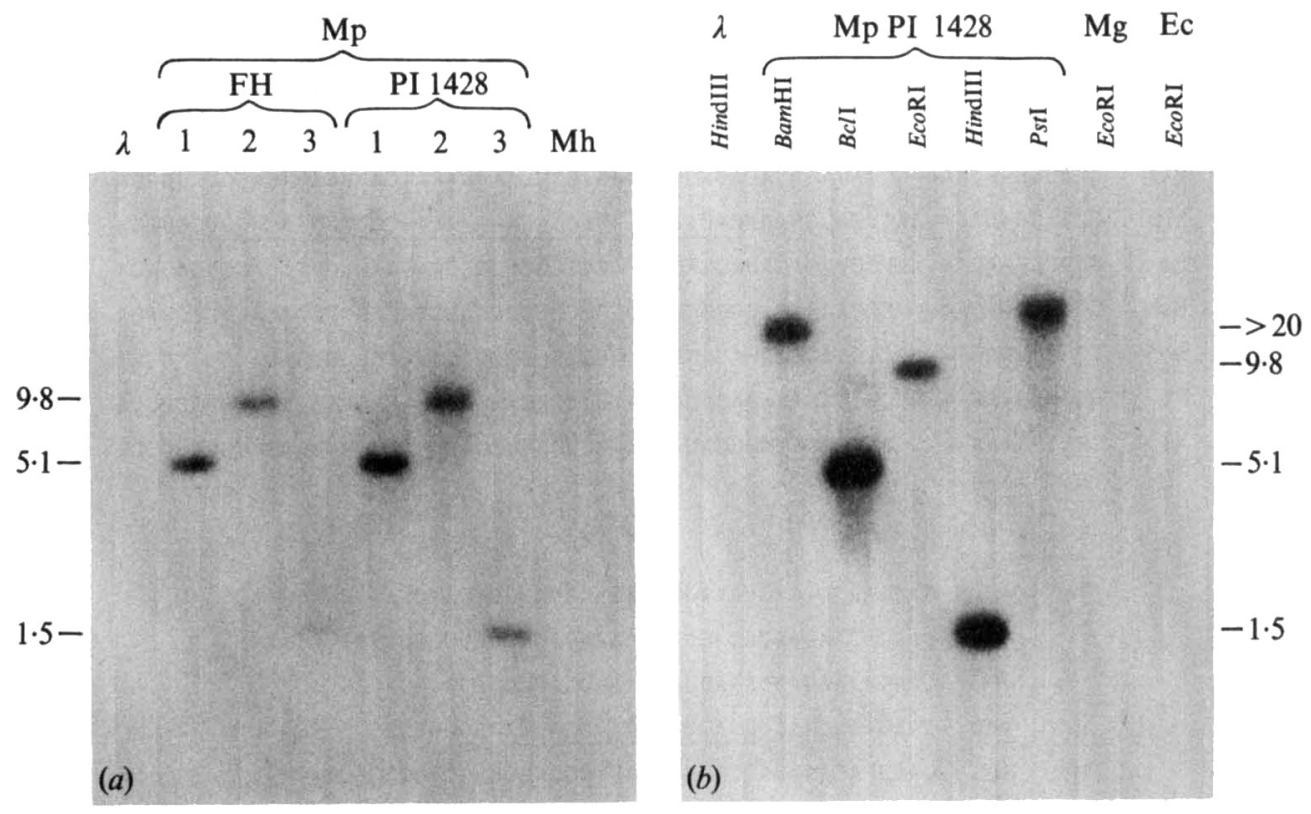

Fig. 2. Specificity of the oligonucleotide probes MP20 (a) and MP30 (b). Genomic DNAs of $M$. pneumoniae (Mp) strains FH and PI $1428, M$. hyorhinis $(\mathrm{Mh}), M$. gallisepticum $(\mathrm{Mg})$ and $E$. coli $(\mathrm{Ec})$ were digested with various restriction enzymes. (a) Lanes 1-3 contained 1-2 $\mu \mathrm{g} B c I-(1), E c o$ RI- (2) and HindIII- (3) digested $M$. pneumoniae DNA. The same amounts of HindIII-digested phage $\lambda(\lambda)$ and $\boldsymbol{M}$. hyorhinis (Mh) DNA were applied to the outside lanes as controls. (b) The same amounts of DNA as given in (a) were applied to each lane. Controls were phage $\lambda, M$. gallisepticum and $E$. coli DNA. The lengths (kbp) of fragments containing parts of the 16S rRNA gene are indicated.

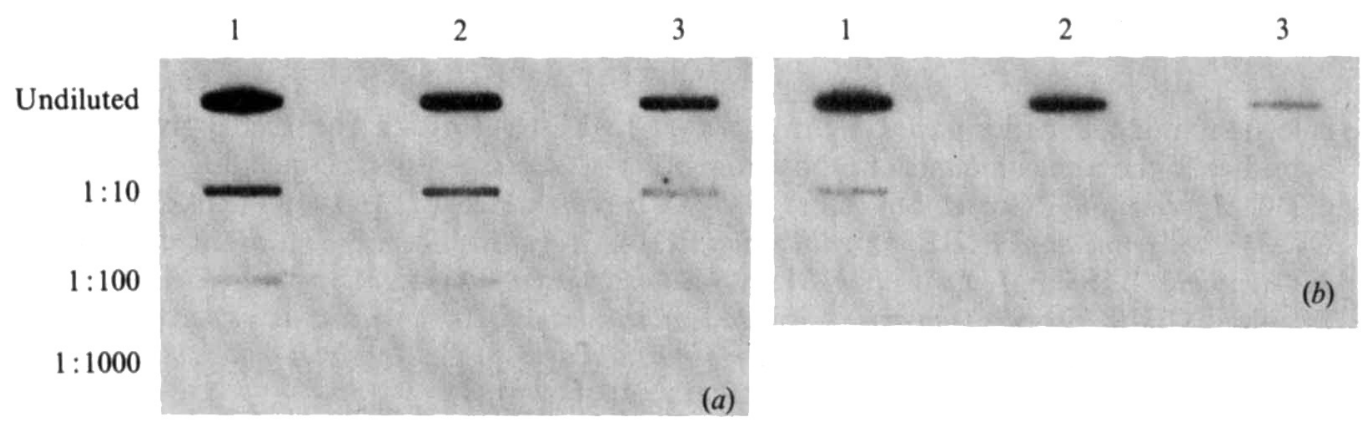

Fig. 3. Sensitivity of a DNA/RNA (a) or DNA/DNA (b) hybridization using the ${ }^{32}$ P-end-labelled 30 base probe (MP30). Using the DNA/RNA hybridization protocol $7 \times 10^{2} M$. pneumoniae c.f.u. could be detected. The numbers of Mycoplasmas in the undiluted suspensions were: $3 \times 10^{5}$ c.f.u. (lane 1); $1.5 \times 10^{5}$ c.f.u. (lane 2); and $7.0 \times 10^{4}$ c.f.u. (lane 3).

suspension which was frozen and thawed repeatedly, at least a 100-fold reduction of the intensity of the hybridization signal was found compared to an equal amount of freshly grown mycoplasmas (Fig. 4), due to endogenous nuclease activity. Neither oligonucleotide probe showed unspecific cross-hybridization with RNA extracted from $M$. pneumoniae-free sputum samples. RNA from $M$. pneumoniae cells added to the appropriate sputum samples was, however, detected with slightly higher sensitivity than RNA of the controls. The reason for this is unknown. Data are shown for MP20 only (Fig. 5).

The technique described here may easily be adapted for the detection or identification of 


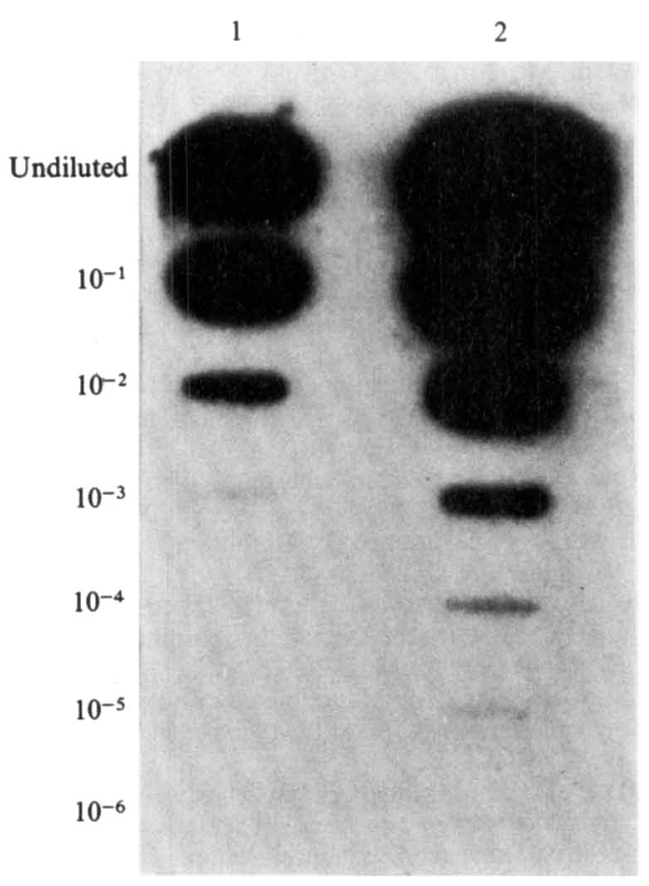

Fig. 4

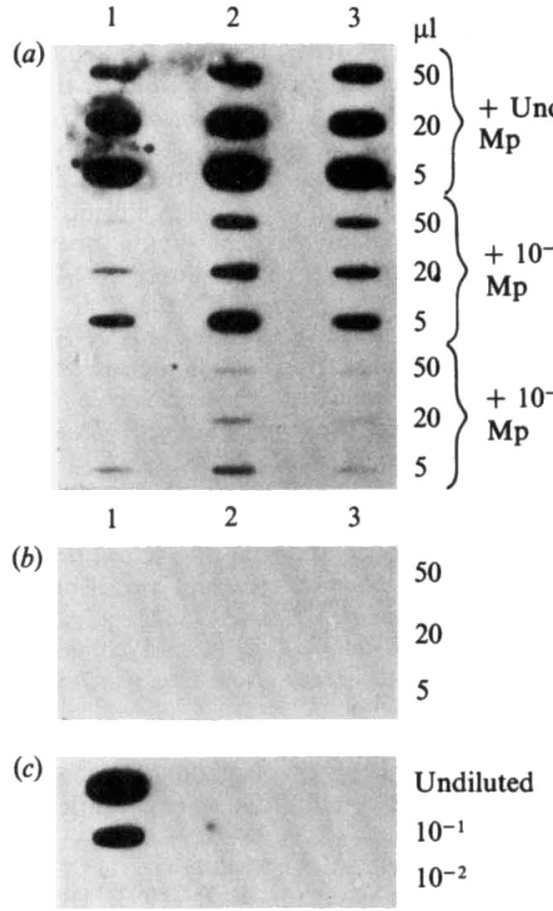

Fig. 5

Fig. 4. Influence of the $M$. pneumoniae sample preparation procedure on the sensitivity of the RNA/DNA hybridization using the MP20 probe. Due to endogenous nuclease activity in thawed cells, signal intensity was reduced about 1000 -fold. Lane 1 , thawed cells; lane 2 , fresh cells.

Fig. 5. Detection of $M$. pneumoniae in sputum specimens using a radiolabelled MP20 probe. (a) Brothgrown $M$. pneumoniae cells at the concentrations indicated were mixed with two $M$. pneumoniae-free sputum samples; (b) sputum control, showing no cross-hybridization; (c) $M$. pneumoniae control; the signal intensity of the $10^{-1}$ dilution corresponds to $10^{4}$ c.f.u. Lane 1 , a sputum sample solubilized with $N$-acetylcysteine; lanes $2-3$, a different sputum sample solubilized with $N$-acetylcysteine and DTT respectively. The volumes of the samples $(\mu \mathrm{l})$ are indicated. Weak signals in slots in which large volumes were applied are due to clogging of the filter membrane by bacterial and cellular debris.

other bacterial species. It combines three attributes of importance to a wide variety of diagnostic applications. (1) A range of probes, varying in specificity from very narrow (as described here) to very wide, can be selected from appropriate domains of the bacterial $16 \mathrm{~S}$ or 23S rRNA. Group-specific probes for Mycoplasma (Göbel \& Stanbridge, 1984) and Legionella (Kohne et al., 1984) derived from more conserved regions of the ribosomal genes have already been reported. An additional application includes the concept of taxonomic 'finger printing' of hitherto unknown or unclassified bacterial species using a set of different oligonucleotides. (2) The high number of rRNA target molecules results in a sensitivity at least 100 times greater than that of bacterial DNA targets (Falkow, 1985; Tompkins et al., 1985; Eisenstein \& Engleberg, 1986). (3) The use of short probes substantially reduces hybridization times and allows exact prediction of the hybridization conditions (Conner et al., 1983).

We wish to thank Drs W. Bredt, P. Chuba and N. Kennedy for critical discussion and Ruth Thomas for preparation of the manuscript. The technical assistance (Figs. 4 and 5) of G. Haun is gratefully acknowledged. This work was supported in part by grants of the Deutsche Forschungsgemeinschaft and the Bundesministerium für Forschung und Technologie (U. B. Göbel) and grants from NIH (E. J. Stanbridge). 


\section{REFERENCES}

AtKinson, T. \& SMITH, M. (1984). Solid phase synthesis of oligodeoxyribonucleotides by the phosphite-triester methods. In Oligonucleotide Synthesis. A Practical Approach, pp. 35-81. Edited by M. J. Gait. Oxford: IRL Press.

Aufrray, C. \& Rougeon, F. (1980). Purification of mouse immunoglobulin heavy-chain messenger RNA's from total mycoplasma tumor RNA. European Journal of Biochemistry 107, 303-314.

Brosius, J., Palmer, L., Kennedy, J. P. \& Noller, H. F. (1978). Complete nucleotide sequence of a 16S ribosomal RNA gene from Escherichia coli. Proceedings of the National Academy of Sciences of the United States of America 75, 4801-4805.

Carbon, P., Ebel, J. P. \& Ehresmann, C. (1981). The sequence of the ribosomal 16S RNA from Proteus vulgaris. Sequence comparison with $E$. coli $16 \mathrm{~S}$ RNA and its use in secondary structure model building. Nucleic Acids Research 9, 2325-2333.

Cassell, G. H. \& Cole, B. C. (1981). Mycoplasmas as agents of human disease. New England Journal of Medicine 304, 80-89.

Chirgwin, J. M., Przybyl, A. E., McDonald, R. J. \& RUTTER, W. J. (1979). Isolation of biologically active ribonucleic acid from sources enriched in ribonuclease. Biochemistry 18, 5294-5299.

Conner, B. J., Reyes, A. A., Morin, C., Itakura, K., TePlitz, R. L. \& Wallace, R. B. (1983). Detection of sickle cell $\beta^{3}$-globin allele by hybridization with synthetic oligonucleotides. Proceedings of the National Academy of Sciences of the United States of America 80, 278-282.

Eisenstein, B. I. \& ENGleberg, N. C. (1986). Applied molecular genetics: new tools for microbiologists and clinicians. Journal of Infectious Diseases 153, 416-430.

FALKow, S. (1985). The use of DNA hybridization for the identification of pathogenic bacteria. In Rapid Methods and Automation in Microbiology and Immunology pp. 30-33. Edited by $K$. O. Habermehl. Berlin: Springer.

Frydenberg, J. \& Christiansen, C. (1985). The sequence of $16 \mathrm{~S}$ rRNA from Mycoplasma strain PG 50. DNA 4, 127-137.

GöBEL, U. \& StANBridge, E. J. (1984). Cloned mycoplasma ribosomal RNA genes for the detection of mycoplasma contamination in tissue cultures. Science 226, 1211-1213.

GöBel, U., SPETH, V. \& BREdT, W. (1981). Filamentous structures in adherent Mycoplasma pneumoniae cells treated with nonionic detergents. Journal of Cell Biology 91, 537-543.

GÖBEL, U., BUTLER, G. H. \& STANBRIDGe, E. J. (1984). Comparative analysis of mycoplasma ribosomal RNA operons. Israel Journal of Medical Sciences 20, 762-764.

Gray, M. W., Sankoff, D. \& Cedergren, R. J. (1984). On the evolutionary descent of organisms and organelles: a global phylogeny based on a highly conserved structural core in small subunit ribosomal RNA. Nucleic Acids Research 12, 5837-5852.

Huysmans, E. \& De WachteR, R. (1986). Compilation of small ribosomal subunit RNA sequences. Nucleic Acids Research 14 (supplement), r73-r118.
Iwami, M., Muto, A., Fumiaki, Y. \& Osawa, S. (1984). Nucleotide sequence of $r m B$ 16S ribosomal RNA gene from Mycoplasma capricolum. Molecular and General Genetics 196, 317-322.

Kohne, D. E., Staigerwalt, A. G. \& Brenner, D. J. (1984). Nucleic acid probe specific for members of the genus Legionella. In Legionella. (Proceedings of the Second International Symposium), pp. 107-108. Edited by C. Thornsberry, A. Balows, J. C. Feeley \& W. J. Jakubowski. Washington, DC: American Society for Microbiology.

MESsing, J. (1983). New M13 vectors for cloning. Methods in Enzymology 101, 20-78.

Morgan, E. A. (1982). Ribosomal RNA genes in Escherichia coli. In The Cell Nucleus, vol. X, pp. 1-29. Edited by H. Busch \& L. Rothblum. New York: Academic Press.

Nomura, M., Morgan, E. A. \& Jaskunas, S. R. (1977). Genetics of bacterial ribosomes. Annual Review of Genetics 11, 297-347.

RAzIN, S. (1985). Molecular biology and genetics of mycoplasmas (Mollicutes). Microbiological Reviews 49, 419-455.

SAlim, M. \& MAden, E. H. (1981). Nucleotide sequence of Xenopus laevis $18 \mathrm{~S}$ ribosomal RNA inferred from gene sequence. Nature, London 291, 205-208.

SANGer, F., Nicklen, S. \& Coulson, A. R. (1977). DNA sequencing with chain-terminating inhibitors. Proceedings of the National Academy of Sciences of the United States of America 74, 5463-5467.

Tompkins, L. S., Nickelsen, P. A. \& Troup, N. (1985). DNA technology applied to the detection and epidemiology of enteric pathogens. In Rapid Methods and Automation in Microbiology and Immunology pp. 68-72. Edited by K. O. Habermehl. Berlin: Springer.

Tully, J. G. \& RAzIN, S. (1983). Methods in Mycoplasmology, vol. II, Diagnostic Mycoplasmology. New York: Academic Press.

Wallace, R. B., Shaffer, J., MURPhy, R. F., Bonner, J., Hirose, T. \& ItAKuRA, K. (1979). Hybridization of synthetic oligodeoxyribonucleotides to $\phi$ XI74 DNA : the effect of single base pair mismatch. Nucleic Acids Research 6, 3543-3557.

Wallace, R. B., Johnson, M. J., Hirose, T., MiYaka, T., Kawashima, E. H. \& ItakuRa, K. (1981). The use of synthetic oligonucleotides as hybridization probes. II. Hybridization of oligonucleotides of mixed sequence to rabbit $\beta$-globin DNA. Nucleic Acids Research 9, 879-894.

Woese, C. R., Gutell, R., GuPta, R. \& Noller, H. F. (1983). Detailed analysis of the higher order structure of 16S-like ribosomal ribonucleic acids. Microbiological Reviews 47, 621-669.

Wu, R., Wu, N. H., Hanna, Z., Georges, F. \& Nasang, S. (1984). Purification and sequence analysis of synthetic oligodeoxyribonucleotides. In Oligonucleotide Synthesis. A Practical Approach, pp. 135151. Edited by M. J. Gaiz. Oxford: IRL Press. 